\title{
PERMINTAAN DAN PENAWARAN
}

Makalah Ini Disusun untuk Memenuhi Tugas

pada Mata Kuliah Ekonomi Mikro Syariah

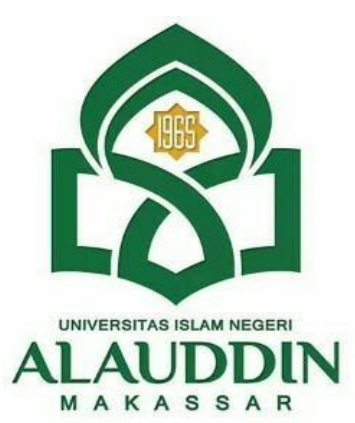

Dosen Pengampu : Samsul, S.A.B., M.A

Disusun Oleh :

KELOMPOK 1

Gusti Yusmiana (90500120109)

Ervie Yuniarti (90500120126)

Winda Aulya (90500120113)

\section{FAKULTAS EKONOMI DAN BISNIS ISLAM}

UNIVERSITAS ISLAM NEGERI ALAUDDIN MAKASSAR

2020/2021 


\section{KATA PENGANTAR}

Puji syukur kita panjatkan kepada Tuhan Yang Maha Esa karena atas rahmat dan karunia-Nya kita dapat menyelesaian makalah "Permintaan dan Penawaran". Dan kami berterima kasih pada bapak Samsul SAB, MA sebagai Dosen mata kuliah Ekonomi Mikro Syariah yang telah memberikan tugas kepada kami.

Kami sangat berharap makalah ini dapat berguna dalam rangka menambah wawasan serta pengetahuan kita sebagai penulis maupun pembaca. Kami menyadari bahwa dalam penulisan makalah ini masih terdapat banyak kekurangan dan jauh dari apa yang kami harapkan. Kami mohon maaf apabila terdapat kesalahan kata kata yang kurang berkenan dalam penulisan makalah ini. Oleh karena itu kami mengharapkan kritik dan saran yang membangun untuk menyempurnakan makalah ini untuk menjadi lebih baik lagi.

Wajo , 20 September 2021

Penulis 


\section{DAFTAR ISI}

PERMINTAAN DAN PENAWARAN ......................................................................................1

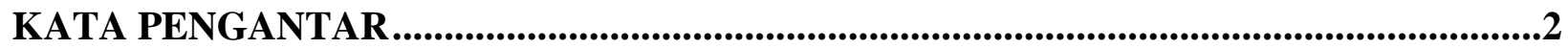

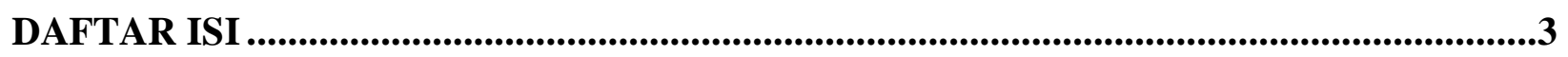

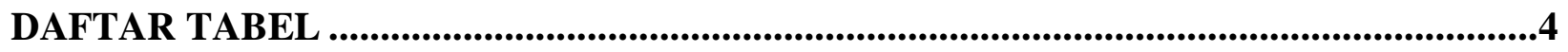

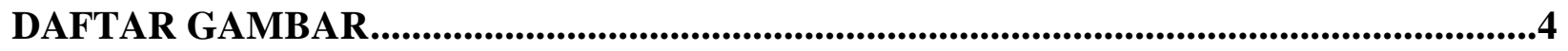

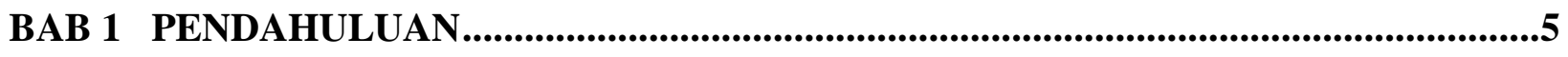

1.1 Latar Belakang ...........................................................................................................................5

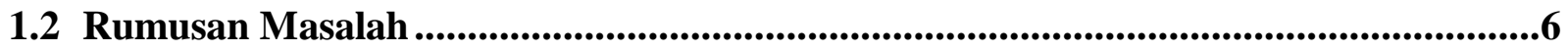

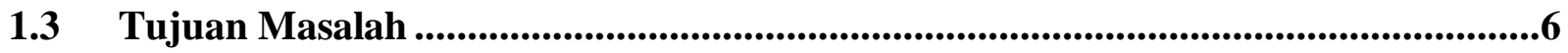

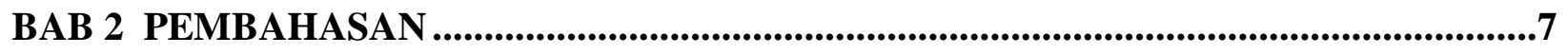

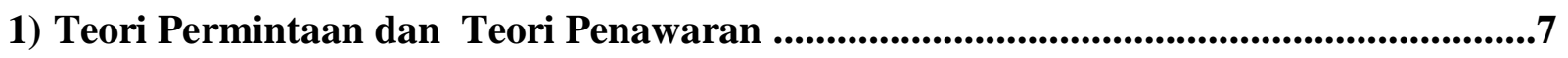

2) Kurva Permintaan Barang Halal .......................................................................14

3) Konsumsi Inter -Temporal Konvensional...............................................................16

4) Konsumsi Inter-Temporal Dalam Islam ..................................................................17

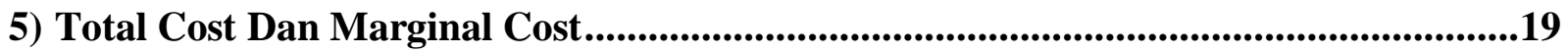

6) Pengaruh Pajak Penjualan .........................................................................................21

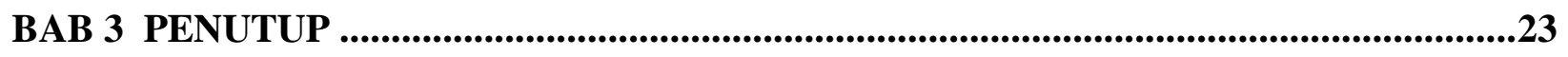

A. Kesimpulan ................................................................................................................23

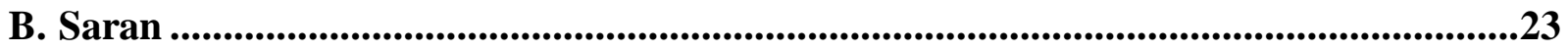

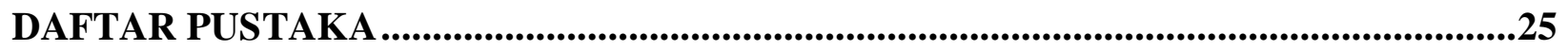




\section{DAFTAR TABEL}

Tabel 1 : Permintaan

Tabel 2 : Hubungan antara faktor yang mempengaruhi permintaan dengan perubahan

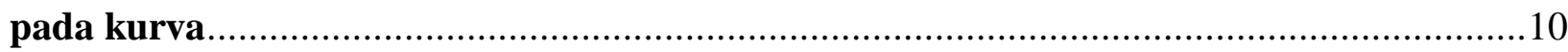

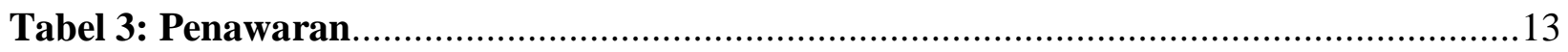

Tabel 4 : Hubungan antara faktor yang mempengaruhi penawaran dengan perubahan

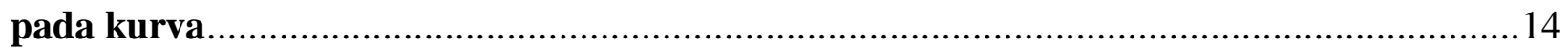

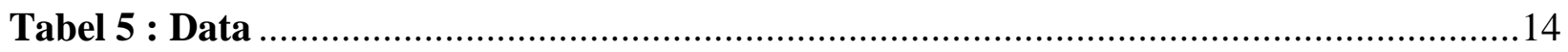

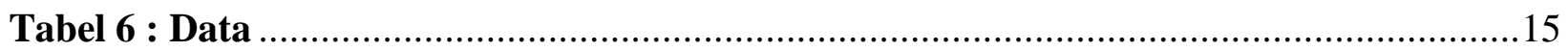

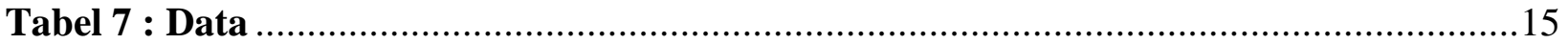

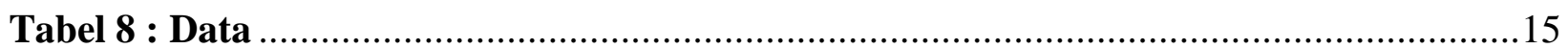

\section{DAFTAR GAMBAR}

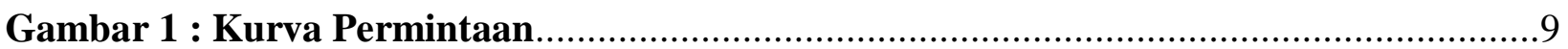

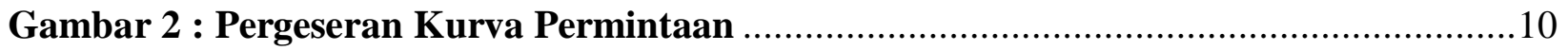

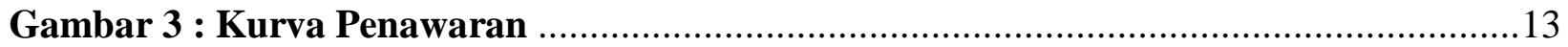

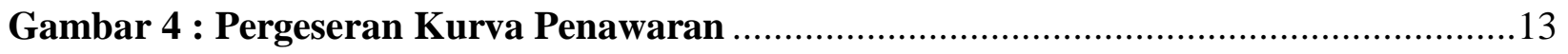

Gambar 5 : Kurva Permintaan Barang Halal .......................................................... 16 


\section{BAB 1 \\ PENDAHULUAN}

\subsection{Latar Belakang}

Dalam ekonomi mikro menjelaskan sebuah pengambilan keputusan dalam setiap unit ekonomi. Pandangan ekonomi islam terhadap permintaan, penawaran ini relatif sama dengan ekonomi konvensional, namun terdapat batasan batasan dari hukum islam untuk berperilaku yang sesuai dengan aturan syariah. Dalam ekonomi islam, norma dan moral islami yang merupakan prinsip islam dalam berekonomi merupakan faktor yang menentukan suatu individu maupun masyarakat dalam melakukan kegiatan ekonominya.

Dalam ilmu ekonomi sehari hari terdapat permintaan (demand) dan penawaran (supply) yang saling mempengaruhi satu sama lain antara pembeli dan penjual di pasar. Pada zaman sekarang ini orang menganggap bahwa ilmu ekonomi adalah ilmu yang hanya dimulai dan diakhiri dengan hukum permintaan dan penawaran. Tentu saja anggapan ini terlalu mengandalkan ilmu ekonomi sebagai ilmu yang sangat sederhana. Namun sebenarnya hukum yang dikenal dengan hukum penawaran dan permintaan memang merupakan bagian yang terpenting dalam pemahaman kita mengenai pasar. Dimana permintaan adalah jumlah barang yang diminta pada jumlah dalam waktu tertentu, sedangkan penawaran adalah jumlah barang atau jasa yang tersedia dan dapat ditawarkan oleh produsen kepada konsumen pada setiap tingkat harga selama periode waktu tertentu. 


\subsection{Rumusan Masalah}

1. Bagaimana teori permintaan dan teori penawaran ?

2. Bagaiman kurva permintaan barang halal ?

3. Bagaimana konsumsi Inter - Temporal konvensional ?

4. Bagaiamana konsumsi Inter - Temporal dalam islam ?

5. Bagaiman total cost dan marginal cost ?

6. Apa saja pengaruh pajak penjualan ?

\subsection{Tujuan Masalah}

1. Untuk menegtahui teori permintaan dan teori penawaran.

2. Untuk menegtahui kurva permintaan barang halal.

3. Untuk menegtahui konsumsi Inter - Temporal konvensional.

4. Untuk menegtahui konsumsi Inter - Temporal dalam islam.

5. Untuk menegtahui total cost dan marginal cost.

6. Untuk menegtahui pengaruh pajak penjualan 


\section{BAB 2}

\section{PEMBAHASAN}

\section{1) Teori Permintaan dan Teori Penawaran}

\section{Teori Permintaan}

Dalam ilmu ekonomi, permintaan disebut dengan istilah demand yang berarti suatu keinginan konsumen untuk membeli suatu barang pada berbagai tingkat harga selama periode waktu tertentu. Permintaan adalah banyaknya jumlah barang yang diminta dalam suatu pasar tertentu, dengan tingkatan harga dan tingkatan pendapatan dalam periode tertentu.

Dalam permintaan islam berperinsip pada entitas utama yaitu islam sebagai pedoman hidup yang langsung dari Allah swt. Konsep permintaan dalam islam ini menilai sesuatu yang tidak semuanya bisa untuk digunakan maupun dikonsumsi, yang dibedakan antara halal atau haram. Dan Allah swt. Berfirman dalam surah Al Maidah ayat 88 :

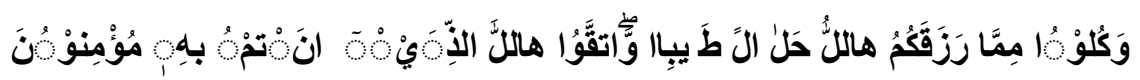

Artinya: "Dan makanlah dari apa yang telah diberikan Allah kepadamu sebagai rezeki yang halal dan baik, dan bertakwalah kepada Allah yang kamu beriman kepadaNya."

Jadi teori yang menerangkan adanya hubungan antara permintaan terhadap harga ini merupakan pernyataan positif, yang biasanya kita kenal dengan teori permintaan. Teori permintaan itu ialah perbandingan lurus antara permintaan terhadap harganya, apabila permintaan itu naik, maka harga itu juga relatif akan naik, begitupun sebaliknya, apabila permintaan itu turun, maka harga itu relatif juga akan turun. Jadi dalam permintaan kita harus menyesuaikan dengan kebutuhan kita bukan hanya sekedar menuruti segala keinginan kita, karena semakin besar permintaan kita terhadap suatu produk, otomatis sumber dayanya pun bisa mengakibatkan kelangkaan bahan produksi. 


\section{Hukum permintaan}

Hukum permintaan adalah makin rendah harga suatu komoditas maka akan semakin banyak jumlah komoditas yang diminta, sebaliknya makin tinggi harga suatu komoditas maka akan semakin sedikit jumlah komoditas yang diminta (dengan asumsi faktor lain konstan atau ceteris paribus). ${ }^{1}$ Permintan seseorang terhadap suatu barang atau jasa dipenagruhi oleh beberapa factor diantaranya yaitu :

1. Harga barang itu sendiri.

2. Harga barang barang lain (merupakan barang subsitusi atau barang komplementer).

3. Pendapatan rata rata masyarakat

4. Selera masyarakat .

5. Jumlah penduduk.

6. Ramalan keadaan di masa mendatang

Dalam hal ini hukum permintaan dapat disimpulkan bahwa sifat hubungan yang terjadi antara jumlah komoditas yang diminta dengan harga adalah hubungan terbalik. Artinya ketika salah satu variabel naik maka variabel lainnya akan mengalami penurunan. Sifat hubungan ini terjadi karena ketika harga komoditas naik maka konsumen akan mengurangi pembelian dan berpindah membeli komoditas pengganti, sebaliknya jika harga komoditas turun maka pembeli akan mengurangi pembelian komoditas pengganti dan akan menambah pembelian terhadap komoditas yang mengalami penurunan harga. ${ }^{2}$

\section{Kurva Permintaan}

Kurva permintaan adalah kurva yang menunjukkan hubungan antara jumlah barang yang diminta pada berbagai tingkat harga, catering paribus. Hubungan permintaan pasar ini dapat mencakup hubungan dalam lingkup yang kecil seperti di desa kota dan lebih

\footnotetext{
${ }^{1}$ Nuraini, I. (2016 ). PENGANTAR EKONOMI MIKRO. Malang : UMM PERS.

${ }^{2}$ Nuraini, I. (2016 ). PENGANTAR EKONOMI MIKRO. Malang : UMM PERS.
} 
jauh lagi tingkat negara atau dunia. Kurva ini mempunyai gradient atau kemiringan atau slope negatif, artinya slope pada kurva ini menurun dari kiri atas ke kanan bawah. Hal ini menunjukkan bahwa hubungan antara harga dengan permintaan adalah berbanding terbalik.

\section{Contoh Kurva Permintaan pada Bakso :}

\section{Tabel 1 : Permintaan}

\begin{tabular}{|c|c|c|}
\hline Titik & $\begin{array}{c}\text { Harga (per mangkok } \\
\text { dalam rupiah) }\end{array}$ & $\begin{array}{c}\text { Jumlah yang } \\
\text { Diminta (mangkok) }\end{array}$ \\
\hline A & Rp20.000,00 & 120 \\
\hline B & Rp18.000,00 & 140 \\
\hline C & Rp16.000,00 & 160 \\
\hline D & Rp14.000,00 & 180 \\
\hline E & Rp12.000,00 & 200 \\
\hline
\end{tabular}

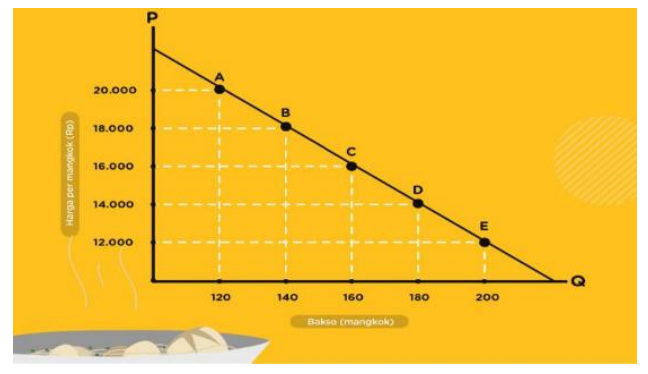

Gambar 1 : Kurva Permintaan

Berdasarkan hukum permintaan gambar kurva selalu digambar miring dari atas ke bawah ini mempunyai arti bahwa ketika permintaan barang barang banyak, maka nilai harga akan menurun. Diartikan juga semakin banyak barang yang dikonsumsi maka manfaat barang akan berkurang. Pergeseran kurva permintaan dapat disebabkan oleh dua faktor utama yaitu faktor ceteris paribus (barang itu sendiri) disesuaikan dengan pendapatan pembeli dan perubahan harga barang pendukung). Bila pendapatan meningkat, kurva permintaan bergeser sejajar ke 
kanan. Jika pendapatan menurun, kurva permintaan bergeser sejajar ke kiri. Contoh ini dapat diilustrasikan dalam kurva berikut ini.

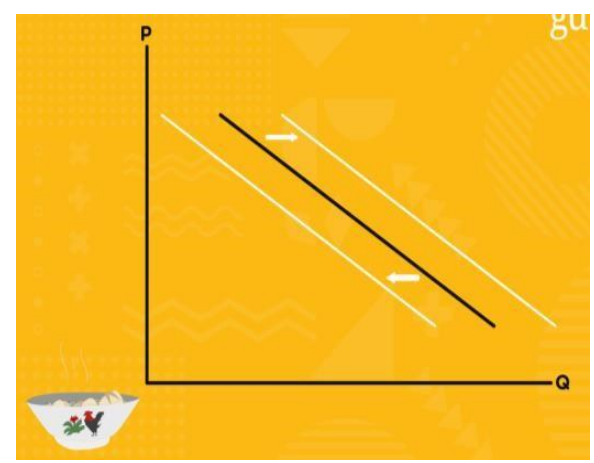

Gambar 2 : Pergeseran Kurva Permintaan

Pengaruh masing-masing faktor yang memengaruhi permintaan terhadap pergerakan (movement) dan pergeseran (shifting) kurva permintaan dapat dirangkum dalam tabel berikut :

Tabel 2 : Hubungan antara faktor yang mempengaruhi permintaan dengan perubahan pada kurva

\begin{tabular}{|l|l|l|l|}
\hline \multirow{2}{*}{$\begin{array}{l}\text { Faktor yang Memengaruhi } \\
\text { Permintaan }\end{array}$} & \multicolumn{2}{|c|}{ Nerubahan Pada Kurva Permintaan Ketika } \\
\hline \multirow{2}{*}{ Harga } & Barang Itu Sendiri & $\begin{array}{l}\text { Bergerak dari kanan } \\
\text { bawah ke kiri atas }\end{array}$ & $\begin{array}{c}\text { Bergerak dari kiri atas } \\
\text { ke kanan bawah }\end{array}$ \\
\cline { 2 - 3 } & Barang Komplementer & Bergeser ke kanan & Bergeser ke kiri \\
\hline Pendapatan & Berger ke kiri & Bergeser ke kanan \\
\hline Selera & Bergeser ke kanan & Bergeser ke kiri \\
\hline Jumlah Penduduk & Bergeser ke kanan & Bergeser ke kiri \\
\hline $\begin{array}{l}\text { Prediksi/Ekspektasi Konsumen } \\
\text { atas Harga Barang Itu Sendiri }\end{array}$ & Bergeser ke kanan & Bergeser ke kiri \\
\hline
\end{tabular}

\section{- Teori Penawaran}

Penawaran adalah barang atau jasa yang ditawarkan pada jumlah dan tingkat harga tertentu dan dalam kondisi tertentu. Hubungan antara jumlah penawaran barang dan jasa dinyatakan dalam hukum penawaran yaitu perbanding lurus anatara harga terhadap 
jumlah yang ditawarkan, artinya apabila harga naik maka penawaran akan meningkat, begitupun sebaliknya apabila harga turun maka penawaran juga akan menurun.

Dan dalam penawaran islami menurut Ibnu Khaldun bahwa kenaikan dalam penawaran akan menyebabkan kenaikan harga, demikian pula sebaliknya. Dari rendahnya harga akan merugikan perajin dan pedagang sehingga mereka akan keluar dari pasar, sedangkan akibat dari tingginya harga akan menyusahkan konsumen, terutama kaum mayoritas miskin. Ibnu Khaldun berpendapat bahwa harga rendah untuk kebutuhan pokok harus diusahakan tanpa merugikan produsen. Allah berfirman dalam surah Luqman ayat 20 :

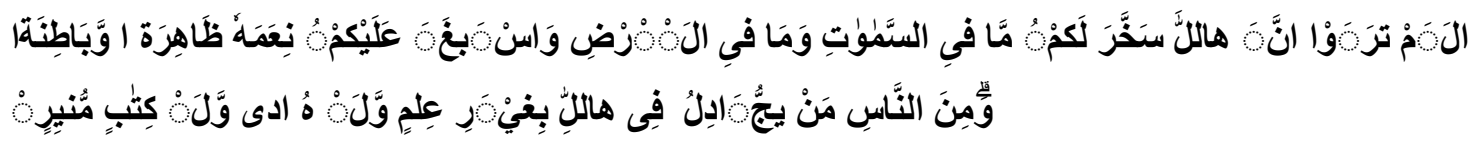

Artinya : "Tidakkah kamu memperhatikan bahwa Allah telah menundukkan apa yang ada di langit dan apa yang ada di bumi untuk (kepentingan)mu dan menyempurnakan nikmat-Nya untukmu lahir dan batin. Tetapi di antara manusia ada yang membantah tentang (keesaan) Allah tanpa ilmu atau petunjuk dan tanpa Kitab yang memberi penerangan."

Makna dalam surah tersebut adalah Allah swt telah meyediakan alam untuk dimanfaatkan untuk keperluan manusia dengan sebaik mungkin. Dalam konsep islam mencegah kerusakan ( mafsadah) lebih utamakan daripada memperbaiki kerusakan dari suatu produk tersebut tentu berpengaruh terhadap fungsi penawaran barang atau jasa

\section{- Hukum Penawaran}

Hukum penawaran menyatakan bahwa semakin tinggi harga suatu barang maka semakin banyak jumlah barang yang ditawarkan sebaliknya Semakin rendah suatu barang maka semakin sedikit jumlah barang yang ditawarkan. Adapun faktor yang menentukan :

1. Harga barang yang ditawarkan.

2. Harga barang lain 


\section{Harga faktor produksi/ bahan produksi}

4. Kebijakan pemerintah

5. Jumlah penjual yang ada

Hukum penawaran merupakan suatu pernyataan yang menjelaskan mengenai sifat hubungan antara harga suatu barang dengan jumlah barang yang ditawarkan. Dalam hukum ini prinsipnya adalah bagaimana keinginan penjual untuk menawarkan barangnya apabila harga. Dalam konteks ini, teori penawaran merupakan teori yang menerangkan sifat penjual dalam menawarkan barang yang akan dijual. Gerakan sepanjang dan pergeseran kurva penawaran perubahan dalam jumlah yang ditawarkan dapat berlaku sebagai akibat dari pergeseran kurva penawaran. Dengan kata lain definisi penawaran bisa juga dijelaskan dengan proses pada umumnya, sumber dan teknik produksi yang digunakan oleh seorang produsen dapat digunakan untuk memproduksi berbagai macam dan jumlah yang diproduksi.

\section{- Kurva Penawaran}

Kurva penawaran adalah merupakan garis yang menghubungkan berbagai jumlah barang yang ditawarkan pada berbagai variasi harga. Dapat juga di didefinisikan sebagai kurva yang menunjukkan hubungan antara nilai harga suatu barang dengan jumlah barang yang ditawarkan atau dijual.

Menurut hukum penawaran kurva penawaran selalu miring dari kiri bawah kekanan atas artinya ketika harga naik produsen akan memasarkan lebih banyak barang. Kurva ini adalah kebalikan dari kurva permintaan. Jika harga suatu barang naik, maka barang yang di tawarkan juga akan naik. Begitulah bunyi hukum pada kurva penawaran. Kurva ini memiliki gradient / kemiringan / slope positif, artinya slope pada kurva ini berjalan naik dari pojok bawah kiri ke pojok kanan atas.

\section{Contoh Kurva Penawaran pada Bakso :}

Penawaran dapat digambar secara grafis sebagai kurva penawaran dengan tabel yang menunjukkan hubungan antara harga barang dengan jumlah yang ditawarkan oleh produsen. 


\section{Tabel 3: Penawaran}

\begin{tabular}{|c|c|c|}
\hline Titik & $\begin{array}{c}\text { Harga (per mangkok } \\
\text { dalam rupiah) }\end{array}$ & $\begin{array}{c}\text { Jumlah yang } \\
\text { Ditawarkan } \\
\text { (mangkok) }\end{array}$ \\
\hline A & Rp20.000,00 & 200 \\
\hline B & Rp18.000,00 & 180 \\
\hline C & Rp16.000,00 & 160 \\
\hline D & Rp14.000,00 & 140 \\
\hline E & Rp12.000,00 & 120 \\
\hline
\end{tabular}

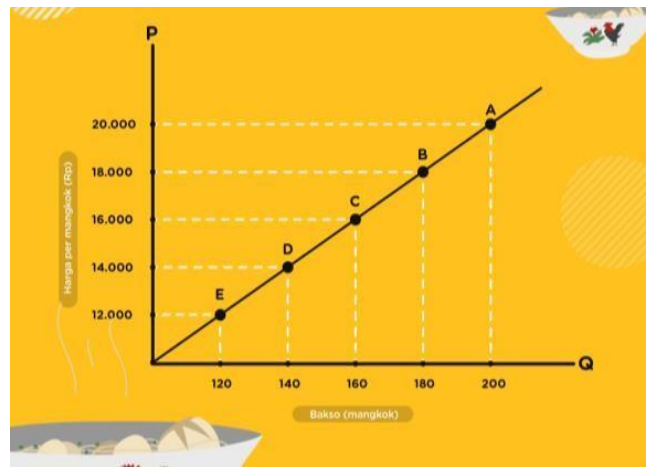

Gambar 3 : Kurva Penawaran

Bila komoditinya meningkat kurva penawaran bergeser sejajar ke kanan. Jika komoditinya menurun, kurva penawaran bergeser sejajar ke kiri. Contoh ini dapat diilustrasikan dalam kurva berikut ini.

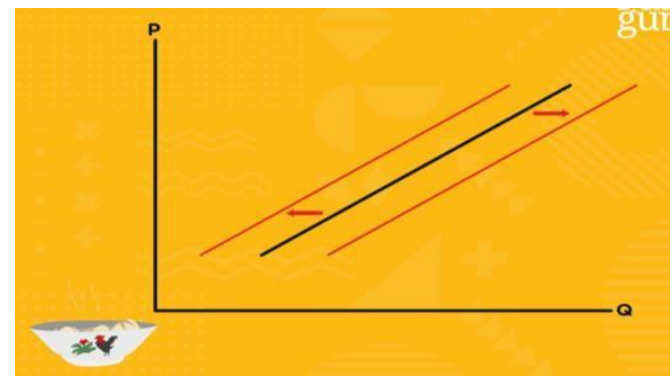

Gambar 4 : Pergeseran Kurva Penawaran 
Pengaruh masing-masing faktor yang memengaruhi penawaran terhadap pergerakan (movement) dan pergeseran (shifting) kurva penawaran dapat dirangkum dalam tabel berikut.

\section{Tabel 4 : Hubungan antara faktor yang mempengaruhi penawaran dengan perubahan pada kurva}

\begin{tabular}{|l|l|l|l|}
\hline \multicolumn{2}{|c|}{$\begin{array}{c}\text { Faktor yang Memengaruhi } \\
\text { Penawaran }\end{array}$} & \multicolumn{2}{c|}{ Nerubahan Pada Kurva Penawaran Ketika } \\
\hline \multirow{2}{*}{ Harga } & Barang Itu Sendiri & $\begin{array}{l}\text { Bergerak dari kiri bawah } \\
\text { ke kanan atas }\end{array}$ & $\begin{array}{l}\text { Bergerak dari kanan atas } \\
\text { ke kiri bawah }\end{array}$ \\
\cline { 2 - 3 } & Barang Terkait & Bergeser ke kiri & Bergeser ke kanan \\
\hline Biaya Produksi & Bergeser ke kiri & Bergeser ke kanan \\
\hline Teknologi & Bergeser ke kanan & Bergeser ke kiri \\
\hline Jumlah Produsen & Bergeser ke kanan & Bergeser ke kiri \\
\hline Kebijakan & Pajak & Bergeser ke kiri & Bergeser ke kanan \\
\cline { 2 - 3 } & Subsidi & Bergeser ke kanan & Bergeser ke kiri \\
\hline $\begin{array}{l}\text { Prediksi/Ekspektasi Konsumen } \\
\text { atas Harga Barang Itu Sendiri }\end{array}$ & Bergeser ke kiri & Bergeser ke kanan \\
\hline
\end{tabular}

\section{2) Kurva Permintaan Barang Halal}

Kurva permintaan diturunkan dari titik titik persinggungan antara indifference curve dengan budget line. Contoh :

Seorang konsumen mempunyai pendapatan I : Rp 1.000.000 per bulan. Dan menghadapi pilihan unuk mengonsumsi barang $\mathrm{X}$ dan Barang $\mathrm{Y}$ yang keduanya adalah barang halal. Bila harga barang $\mathrm{X}, \mathrm{Px}=\mathrm{Rp} 100$ ribu, dan harga barang Y, Py = Rp 200 ribu. Titik A, A', A” menunjukan konsumsi seluruhnya dialokasikan pada barang $\mathrm{X}$ dan titik $\mathrm{B}$ menunjukkan konsumsi seluruhnya dialokasikan pada barang Y. Dengan data ini, dapat dibuat garis anggaran dengan menarik garis lurus antara dua titik.

Tabel 5 : Data

\begin{tabular}{|l|l|l|l|l|l|l|}
\hline Kombinasi & Income & Px & Py & $\begin{array}{l}\mathrm{X}= \\
\mathrm{I} / \mathrm{Px}\end{array}$ & $\mathrm{Y}=\mathrm{I} / \mathrm{Py}$ & $\begin{array}{l}\mathrm{X} \\
\text { tangency }\end{array}$ \\
\hline $\mathrm{A}$ & 1.000 .000 & 100.000 & 200.000 & 10 & 0 & 3 \\
\hline $\mathrm{B}$ & 1.000 .000 & 100.000 & 200.000 & 0 & 5 & 3 \\
\hline
\end{tabular}


Bila terjadi penurunan harga $\mathrm{X}$ sebesar Rp.50 ribu, maka kaki garis anggaran pada sumbu $\mathrm{X}$ akan bertambah panjang. Titik perpotongan sumbu $\mathrm{Y}$ tidak berubah, sedangkan titik perpotongan dengan sumbu $\mathrm{X}$ berubah.

Tabel 6 : Data

\begin{tabular}{|l|l|l|l|l|l|l|}
\hline Kombinasi & Income & Px & Py & $\begin{array}{l}\mathrm{X}= \\
\mathrm{I} / \mathrm{Px}\end{array}$ & $\mathrm{Y=I} / \mathrm{Py}$ & $\begin{array}{l}\mathrm{X} \text { at } \\
\text { tangency }\end{array}$ \\
\hline A' & 1.000 .000 & 50.000 & 200.000 & 20 & 0 & 4 \\
\hline B & 1.000 .000 & 50.000 & 200.000 & 0 & 5 & 4 \\
\cline { 1 - 1 } & & & & & & \\
\hline
\end{tabular}

Bila harga $\mathrm{X}$ menjadi $\mathrm{Px}=\mathrm{Rp} .25 .000$ maka kaki garis anggaran pada sumbu $\mathrm{X}$ akan bertambah panjang. Titik perpotongan sumbu $\mathrm{Y}$ tidak berubah, sedangkan titik perpotongan sumbu $\mathrm{X}$ berubah.

Tabel 7 : Data

\begin{tabular}{|l|l|l|l|l|l|l|}
\hline Kombinasi & Income & Px & Py & $\begin{array}{l}\mathrm{X}= \\
\text { I/Px }\end{array}$ & Y=I/Py & $\begin{array}{l}\text { X at } \\
\text { tangency }\end{array}$ \\
\hline A" & 1.000 .000 & 25.000 & 200.000 & 40 & 0 & 5 \\
\hline B & 1.000 .000 & 25.000 & 200.000 & 0 & 5 & 5 \\
\hline
\end{tabular}

Dengan simulasi harga barang $\mathrm{X}$, akan didapatkan kurva yang menggambarkan antara harga dengan jumlah barang $X$ yang diminta.

Tabel 8 : Data

\begin{tabular}{|l|l|}
\hline Harga X & Jumlah X (X pada saat tangency/jumlah optimal X) \\
\hline 100.000 & 3 \\
\hline 50.000 & 4 \\
\hline 25.000 & 5 \\
\hline
\end{tabular}


Semakin tinggi harga, semakin sedikit jumlah barang yang diminta. Dengan demikian didapatkan kemiringan kurva permintaan yang negatif untuk barang halal, sebagaimana lazimnya kurva permintaan yang dipelajari dalam ekonomi konvensional.

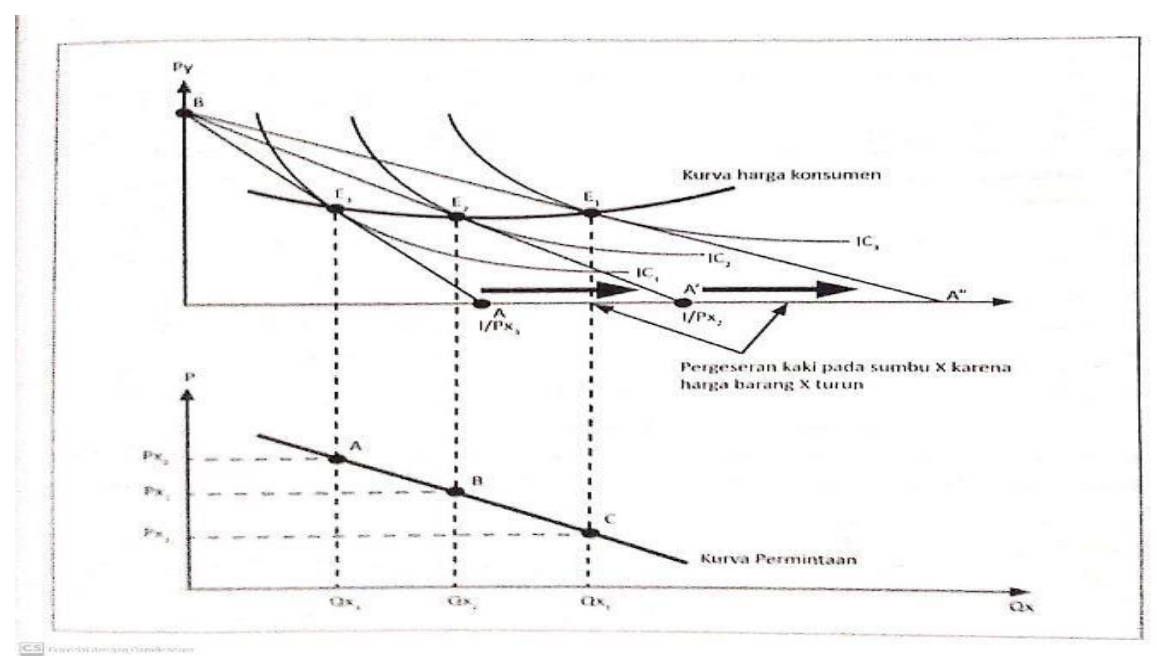

Gambar 5 : Kurva Permintaan Barang Halal

\section{3) Konsumsi Inter -Temporal Konvensional}

Konsumsi inter-temporal adalah konsumsi yang dilakukan dalam dua waktu, yaitu masa sekarang (periode pertama) dan masa yang akan datang (periode kedua). Dalam ekonomi konvensional, pendapatan adalah penjumlahan konsumsi dan tabungan. Atau secara matematis ditulis:

$$
\mathrm{Y}=\mathrm{C}+\mathrm{S}
$$

Keteranagan : Y : Pendapatan

$$
\begin{aligned}
& \mathrm{C}: \text { Konsumsi } \\
& \mathrm{S}: \text { Tabungan }
\end{aligned}
$$

Misalkan pendapatan, konsumsi, tabungan pada periode pertama adalah Y1, C1, S1 dan pendapatan, konsumsi dan saving periode kedua adalah Y2, C2 dan S2 maka persamaan di atas dapat dituliskan sebagai berikut: 
Pendapatan pada periode pertama adalah:

$$
\mathrm{Y} 1=\mathrm{C} 1+\mathrm{S} 1
$$

Pendapatan pada periode kedua adalah:

$$
\mathrm{Y} 2=\mathrm{C} 2+\mathrm{S} 2
$$

Apabila konsumsi di periode pertama lebih kecil daripada pendapatan, maka akan terjadi saving dan konsumsi di periode kedua semakin besar.

$$
\begin{aligned}
\mathrm{Y} 1 & =\mathrm{C} 1+\mathrm{S} 1 \text { dan } \mathrm{C} 1< \\
\mathrm{Y} 1 \mathrm{Y} 2 & =\mathrm{C} 2+\mathrm{S} 2 \\
& =(\mathrm{C} 2+\mathrm{S} 1)+\mathrm{S} 2
\end{aligned}
$$

Pada prinsipnya prilaku konsumen di mana terjadi selisih antara pendapatan dengan jumlah uang yang digunakan untuk konsumsi, dapat dibagi menjadi tiga:

1. Lender, di mana jumlah lebih kecil daripada pendapatan.

2. Borrower, di mana jumlah konsumsi lebih besar daripada pendapatan.

3. Polonius poin, di mana jumlah konsumsi sama dengan jumlah pendapatan ${ }^{3}$.

\section{4) Konsumsi Inter-Temporal Dalam Islam}

Konsumsi inter temporal konsumsi yang dilakukan dalam waktu dua waktu yaitu pada masa sekarang ( periode pertama) dan masa yang akan datang ( periode kedua ). Monzer Kahf yang berusaha mengembangkan pemikiran tentang hal ini, dengan memulai membuat asumsi sebagai berikut: ${ }^{4}$

1. Islam dilaksanakan oleh masyarakat.

2. Zakat hukumnya wajib.

3. Tidak ada riba dalam perekonomian

4. Mud rabah wujud dalam perekonomian.

\footnotetext{
${ }^{3}$ Ir. Adimarwan A. Karim, S. M. (2017). Ekonomi Mikro Islami Edisi 5. Depok: PT Raja Grafindo Persada Hal 115

${ }^{4}$ Ir. Adimarwan A. Karim, S. M. (2017). Ekonomi Mikro Islami Edisi 5. Depok: PT Raja Grafindo Persada. Hal 117
} 
5. Pelaku ekonomi bersikap rasional dengan memaksimalkan kemaslahatan.

Beberapa instrumen dalam ekonomi Islam tentu berdampak pula kepada perubahan perilaku konsumsi bila tanpa instrumen ekonomi Islam tersebut. Beberapa instrumen yang dapat memengaruhi volume jumlah uang dialokasikan untuk konsumsi baik pada periode satu atau dua meliputi:

Zakat; pengenaan zakat pada periode 1 (Z1) akan mengurangi m1 yang dialokasikan untuk $\mathrm{C} 1$. Bila tidak ada tabungan atau peminjaman pada periode 1 maka final spending $(\mathrm{m} 1=\mathrm{FS}=\mathrm{C} 1+\mathrm{Z} 1)$ sama dengan $\mathrm{m} 1$.

Infak atau shadaqah; pengeluaran infak atau shadaqah pada periode 1 akan mengurangi $\mathrm{m} 1$ yang dialokasikan untuk $\mathrm{C} 1$. Tidak ada tabungan atau peminjaman pada periode satu maka final spending sama dengan $\mathrm{m} 1$.

$>$ Rate of profit atau pendapatan bagi hasil (rp); apabila pada periode 1 ada sebagian m1 yang dialokasikan dalam bentuk tabungan dan diinvestasikan maka final spending periode 2 (FS2) sama dengan $\mathrm{m} 2$ jumlah $\mathrm{m} 1$ yang ditabung ditambah dengan rate of profit $(\mathrm{rp})(\mathrm{FS} 2=\mathrm{m} 2+(1+\mathrm{rp}) \mathrm{m} 1) .^{5}$

Dalam konsep Islam yang dijelaskan oleh hadis Rasulullah yang maknanya adalah "Yang kamu miliki adalah apa yang telah kamu makan dan apa yang telah kamu infakkan". Oleh karena itu, persamaan pendapatan menjadi : $\mathrm{Y}=(\mathrm{C}+$ infak $)+\mathrm{S}$

Secara grafis, hal ini seharusnya digambarkan dengan tiga dimensi. Namun, untuk kemudahan penyajian grafis, yaitu dengan dua dimensi, maka persamaan ini disederhanakan menjadi:

$$
\mathbf{Y}=\mathbf{F S}+\mathbf{S}
$$

Di mana: FS $=\mathrm{C}+$ infak

FS adalah final spending (belanja akhir) di jalan Allah ${ }^{6}$.

\footnotetext{
${ }^{5}$ Ir. Adimarwan A. Karim, S. M. (2017). Ekonomi Mikro Islami Edisi 5. Depok: PT Raja Grafindo Persada hal 117

${ }^{6}$ Ir. Adimarwan A. Karim, S. M. (2017). Ekonomi Mikro Islami Edisi 5. Depok: PT Raja Grafindo Persada
} 
Penyederhanaan ini menggunakan alat analisis grafis yang biasa digunakan dalam teori konsumsi, yaitu memaksimalkan fungsi utility dengan garis pendapatan tertentu, atau meminimalkan budget line. Dalam ekonomi konvensional, kebutuhan ditentukan oleh konsep kepuasan (utility) sehingga pembagian kebutuhan tersebut dibagi berdasarkan tingkat intensitas, sifat, subjek yang membutuhkan dan waktu sedangkan dalam ekonomi Islam kebutuhan ditentukan oleh konsep mashlahah yang membagi kebutuhan menjadi tiga, yaitu; kebutuhan dharuriyah, kebutuhan hajiyah, kebutuhan tahsiniyah. Konsep mashlahah dalam ekonomi Islam bertujuan untuk mencapai falah berdasarkan pada prinsip-prinsip Al-Qur'an dan As-Sunnah. ${ }^{7}$

\section{5) Total Cost Dan Marginal Cost}

\section{- Total cost atau biaya total}

Total cost adalah biaya total yang dikeluarkan sebuah bisnis dalam satu periode produksi. Periode produksi adalah serangkaian proses mulai dari membeli bahan baku, mengolah, hingga mendistribusikan barang ke konsumen.

Rumus biaya total (total cost) yaitu sebagai berikut:

$$
\mathbf{T C}=\mathbf{F C}+\mathrm{VC}
$$

Keterangan $: \mathrm{TC}=$ Biaya total $($ total cost)

$\mathrm{FC}=$ Biaya tetap (fixed cost)

$\mathrm{VC}=$ Biaya variabel (variable cost)

Total cost ini terdiri dari fixed cost dan variable cost. Dimana fixed cost atau biaya tetap merupakan biaya yang harus dikeluarkan oleh produsen tanpa memandang jumlah output yang dihasilkan. Dinamakan biaya tetap karena biaya ini tidak mengalami perubahan, meski tak ada kegiatan produksi apapun. Sementara variable cost adalah

\footnotetext{
7 Samsul, S. (2019). Analisis Pemanfaatan harta dalam Konsumsi Masyarakat Ekonomi Konvensional dan Ekonomi Islam. Al-Azhar Journal of Islamic Economics, 1(2), 110-130.
} 
biaya yang jumlahnya bervariasi. Jumlah tersebut sesuai dengan output yang dihasilkan.

\section{Cara Menghitung Biaya Total:}

1. Hitung besarnya biaya tetap.

Pengertian biaya tetap adalah pengeluaran yang harus dibayar setiap bulan seperti biaya sewa, biaya utilitas, tagihan telepon, bahan bakar untuk kendaraan bermotor, belanja bahan makanan dan kebutuhan yang lain. Besarnya biaya tetap tidak akan terlalu banyak berubah, bahkan ada biaya yang tidak berubah sama sekali, dari bulan ke bulan. Biaya ini tidak akan bertambah atau berkurang setiap bulannya karena angkanya tidak tergantung pada pengeluaran untuk memenuhi kebutuhan pribadi

2. Jumlahkan semua biaya variabel Anda selama satu bulan.

Bertolak belakang dengan biaya tetap, besarnya biaya variabel tergantung pada gaya hidup Anda dan semua pengeluaran yang tidak terlalu penting, tetapi dapat meningkatkan kualitas hidup Anda.

3. Jumlahkan biaya tetap dan biaya variabel yang dihitung untuk mengetahui besarnya biaya total. Biaya total yang harus dianggarkan untuk membiayai seluruh kebutuhan hidup adalah jumlah uang yang harus dikeluarkan untuk periode satu bulan. Rumusnya adalah Biaya Tetap + Biaya Variabel = Biaya Total.

4. Catatlah setiap pengeluaran untuk mengetahui pengeluaran bulanan dimiliki.

Pencatatan biaya adalah hal mencatat pengeluaran untuk tempat tinggal (biaya sewa, dll.) dan simpanlah semua tagihan perbulanan yang penting.

\section{Marginal cost atau biaya marjinal}

Marginal cost merupakan penurunan atau peningkatan dari total biaya suatu perusahaan. Biasanya, hal semacam ini terjadi karena adanya penambahan ataupun pengurangan satu unit produk tambahan. Misalnya, marginal cost ini bisa mengalami penurunan jika volume produksi meningkat.

Cara menghitung biaya marjinal adalah dengan membagi pelengkap TC (total cost) dengan rumus: Marginal cost $=$ total average cost: average product

$$
\mathrm{MC}=\Delta \mathrm{TC} / \Delta \mathrm{Q}
$$


Keterangan:

$\mathrm{MC}=$ Biaya marginal $($ marginal cost $)$

$\Delta \mathrm{TC}=$ Perubahan biaya total (total cost)

$\Delta \mathrm{Q}=$ Perubahan kualitas barang dan jasa

Menghitung marginal cost bisa dilakukan dengan tiga langkah, yaitu:

- Langkah 1: Tentukan Perubahan Kuantitas.

Menghitung marginal cost yaitu dengan mengetahui biaya total yang diperlukan untuk memproduksi satu unit produk atau jasa yang dihasilkan perusahaan.

- Langkah 2: Hitung Perubahan Biaya

Dengan menghitung perubahan biaya. Perubahan biaya didapat dari pengurangan total biaya produksi lama dengan biaya produksi yang baru.

- Langkah 3: Menghitung Marginal Cost

Marginal cost adalah biaya yang diperlukan untuk memproduksi satu unit produk tambahan. Yaitu menghitung marginal cost dilakukan untuk mengetahui kenaikan biaya yang diperlukan untuk setiap tambahan unit produksi. Marginal cost didapat dengan membagi perubahan biaya produksi yang diperlukan dengan perubahan kuantitas produk. Bisa juga dengan rumus yaitu $\mathrm{MC}=\mathrm{TC} / \mathrm{Q} . \mathrm{MC}$ adalah Marginal Cost (biaya marginal), TC adalah perubahan biaya produksi, dan Q adalah perubahan kuantitas produk.

\section{6) Pengaruh Pajak Penjualan}

Pajak penjualan adalah pajak yang di kenakan oleh pemerintah dan di bayar pada waktu jual beli ke atas barang-barang yang dikenakan pajak penjualan itu dilakukan. Pada umumnya pajak penjualan dikenakan dalam bentuk suatu persentasi tertentu dari hasil penjualan. Misalnya Rp100 Per liter bensin premium,atau misalnya 10\% dari harga per unit,akan meningkatkan Average total cost. Peningkatan ATC secara langsung juga berarti peningkatan MC. Bila harga tetap pada tingkat harga semula, maka peningkatan biaya ini berarti Penurunan profit.Karena total revenue tetap sedangkan fotal cost meningkat. 
Sebelum Adanya pajak penjualan,ringkat profit sebesar profit,.Dengan adanya pengenaan pajak Penjualan,tingkat profit menurun menjadi profit. ${ }^{8}$

Secara grafis keadaan tanpa adanya pajak penjualan digambarkan pada diagram yang atas oleh kurva average total cost (ATC), dan kurva marginal cost (MC). Harga berada pada tingkat .Sedangkan diagram bawah menggambarkan fungsi profit yang diturunkan dari diagram atas. Profit mencapai keadaan maksimum ketika kurva MC, = P, Ini terjadi pada tingkat produksi Q*- Secara paralel kita dapat pula mengatakan bahwa producer surplus dengan adanya pajak penjualan lebih kecil dibandingkan producer Surplus tanpa adanya pajak penjualan.

Pajak sangat berpengaruh terhadap atas penjualan selalu menambah harga barang yang ditawarkan. Sehingga hanya mempengaruhi fungsi penawaran. Sedangkan pada fungsi permintaan tidak mengalami perubahan sama sekali. ${ }^{9}$

Jadi pengenaan pajak penjualan membawa pengaruh:

1. Turunnya total profit dari profit, menjadi profit

2. Turunnya tingkat profit maksimal yang digambarkan oleh puncak gunung kurva profit pada diagram bawah. Secara grafis, puncak kurva profit, lebih tinggi daripada Puncak kurva profit,.

3. Mengecilnya rentang skala produksi dari Q1 'Q1 “ menjadi Q2'Q2”. Dimana Q1'< Q2'dan Q1'Q2'.

8 Ir. Adimarwan A. Karim, S. M. (2017). Ekonomi Mikro Islami Edisi 5. Depok: PT Raja Grafindo Persada

9 Purnama, N. I. (2016). Pengaruh Pajak dan Subsidi Pada Keseimbangan Pasar. Jurnal Ekonomi dan Studi Pembangunan, 16(1), $32-37$. 


\section{BAB 3 \\ PENUTUP}

\section{A. Kesimpulan}

Permintaan adalah makin rendah harga suatu komoditas maka akan semakin banyak jumlah komoditas yang diminta, sebaliknya makin tinggi harga suatu komoditas maka akan semakin sedikit jumlah komoditas yang diminta. Sedangkan penawaran menyatakan bahwa semakin tinggi harga suatu barang maka semakin banyak jumlah barang yang ditawarkan, begitupun sebalikn Semakin rendah suatu barang maka semakin sedikit jumlah barang yang ditawarkan. Dalam konsumsi inter temporal konvensional, pendapatan adalah penjumlahan konsumsi dan tabungan atau secara matematis di tulis yaitu : $\mathrm{Y}=\mathrm{C}+\mathrm{S}$. Sedangkan dalam konsumsi inter temporal islam, persamaan pendapatan yaitu : $\mathrm{Y}=(\mathrm{C}+$ infak) $+S$. Total cost terdiri dari fixed cost dan variable cost. Total cost ini memiliki rumus yaitu $:$ TC $=$ FC + VC sedangkan Marginal cost adalah dengan membagi pelengkap dari $\mathrm{TC}$ (total cost) dengan rumus : $\mathrm{MC}=\Delta \mathrm{TC} / \Delta \mathrm{Q}$. Adapun pajak sangat berpengaruh terhadap atas penjualan selalu menambah harga barang yang ditawarkan. Sehingga hanya mempengaruhi fungsi penawaran. Sedangkan pada fungsi permintaan tidak mengalami perubahan sama sekali.

\section{B. Saran}

Penulis menyarankan :

1. Kepada para pedagang dan pembeli agar sekiranya untuk sama-sama menjaga mekanisme permintaan dan penawaran agat harga tercipta secara stabil.

2. Kemudian bagi para cendikiawan muslim, hendaknya dapat meneliti lebih lanjut pendapat-pendapat lain dari Ibnu Khaldun agar dapat di kembangkan sesuai dengan perkembangan zaman, ketentuan pendapat tentang ekonomi Islam, serta pendapat lain tentang teori ekonomi masa sekarang. 
3. Diharapkan kepada semua komponen masyarakat untuk senantiasa menjadi sosial kontrol dalam berbagai aktivitas ekonomi, terhadap para pelaku ekonomi itu sendiri agar mereka menjalankan aktivitasnya sesuai dengan syari'at Islam 


\section{DAFTAR PUSTAKA}

Afif, M. (2017). Teori Permintaan dan Konsumsi Inter -Temporal Antara Islam Dan Konvensional. Jurnal Ekonomi Syariah, 2(2), 230-242.

Ahmad Syafii, M. H. (2020). EkonomiI Mikro. Medan: Yayasan Kita Menulis.

Elvira, R. (2015). Teori Permintaan (Komparasi Dalam Perspektif Ekonomi Konvensional Dengan Ekonomi Islam). Jurnal Islamika, 15(1), 47 - 60.

Febianti, Y. N. (2014). Permintaan Dalam Ekonomi Mikro. Edunomic Jurnal Pendidikan Ekonomi, 2(1), 16 - 23.

Hafid, A. (2015). Konsep Penawaran Dalam Perspektif Islami. Jurnal Ekonomi Dan Bisnis Islam, 1(2), 203 - 216.

Hj. Dwika Lodia Putri, S. (2021). Pengantar Ekonomi Mikro. Sumatra Barat: INSAN CENDEKIA MANDIRI.

Ir. Adimarwan A. Karim, S. M. (2017). Ekonomi Mikro Islami Edisi 5. Depok: PT Raja Grafindo Persada.

Muawanah, M. (2017). Permintaan Dan Penawaran Dalam Islam. Jurnal Syariah Dan Hukum Islam, 2(2), 111 - 127.

Nuraini, I. (2016). Pengatar Ekonomi Mikro. Malang: UMM PERS.

Purnama, N. I. (2016). Pengaruh Pajak dan Subsidi Pada Keseimbangan Pasar. Jurnal Ekonomi dan Studi Pembangunan, 16(1), 32 -37.

Samsul, S. (2019). Analisis Pemanfaatan harta dalam Konsumsi Masyarakat Ekonomi Konvensional dan Ekonomi Islam. Al-Azhar Journal of Islamic Economics, 1(2), 110130.

Sya'diah, A. N. (2021). Teori Keseimbangan Umum Dalam Ekonmi Islam. Jurnal Ilmu Akuntansi dan Bisnis Syariah, 3(2), 60 - 74.

Tri Kunawanngsih Pracoyo, A. P. (2006). Aspek Dasar Ekonomi Mikro. Jakarta: PT Gramedia Widiasarana Indonesia. 